\title{
Estratégias cimarronas para narrar a negritude no século XIX em Autobiografía de Juan Francisco Manzano (Cuba, 1835) e Úrsula (Brasil, 1859)
}

Resumo:

A presente reflexão analisará as estratégias narrativas utilizadas por dois escritores negros latino-americanos ao apresentar a temática da negritude no século XIX. De um lado, a autobiografia escrita pelo cubano Juan Francisco Manzano (1835), único texto autobiográfico escrito por homem negro escravizado semi-alfabetizado latino-americano que narra sua vida em troca de liberdade. De outro lado, a narrativa desenvolvida por Maria Firmina dos Reis, mulher, negra liberta considerada a primeira romancista do Brasil: Úrsula (1859), texto abolicionista cujos protagonistas são brancos, surpreende por conceder a voz aos cativos, que narram suas memórias de África e estão conscientes de sua condição. Serão utilizados os referenciais teóricos sobre o romance como gênero de projeção de um futuro ideal das recentes nações latino-americanas (Sommer, 2004), textos abolicionistas como romance de tese (Jeffers, 2013), máscara do silenciamento (Kilomba, 2019) e a pedagogia da cimarronagem (Mendes, 2019) na intenção de revisar o cânone literário latino-americano em uma proposta de inclusão das duas obras como leituras obrigatórias nos cursos de Literatura nas universidades da América Latina.

\section{Palavras-chave:}

Autoria negra no século XIX, Romance latino-americano, Pedagogia da cimarronagem, Juan Francisco Manzano, Maria Firmina dos Reis

\section{Abstract:}

This reflection will analyze the strategies used by two Latin American black writers to present the theme of blackness in the 19th century. On one side, the autobiography written by the cuban Juan Francisco Manzano (1835), the only autobiography text that shows one Latin American semiliterate slave black man that narrates your life in exchange for your liberty. On the other side the narrative written by Maria Firmina dos Reis, a free black woman considered the first female novelist in Brazil: Úrsula (1859), an abolitionist text whose main characters are white, surprises by giving voice to the slave people, who narrate their memories in Africa and are aware of their condition. Theoretical references will be used about the novel as a form of projection of an ideal future (Sommer, 2004), abolitionist texts as thesis novel (Jeffers, 2013), mask of speechlessness (Kilomba, 2019) and cimarronagem's pedagogy (Mendes, 2019) intending to revise the 
Latin American literary canon in an inclusion proposal the two narratives to mandatory readings in the Literature studies in the Latin American universities.

\section{Keywords:}

19th century black authorship, Latin American novel, Cimarronagem pedagogy, Juan Francisco Manzano, Maria Firmina dos Reis

\section{Preliminares}

Na primeira metade do século XX, um grupo de críticos e teóricos latino-americanos buscou estabelecer uma agenda continental que desse conta de construir categorias de interpretação de uma recente literatura que, a partir de 1960, passou a fazer parte do que foi considerado o boom latino-americano. Ao identificar os limites físicos das cidades como representação da hierarquia social imposta pelas sociedades europeias, o teórico uruguaio Ángel Rama propõe, em A cidade das letras (1985) uma reflexão comparativa entre a estrutura das cidades na América Latina e sua relação com as formas de poder estabelecidas no espaço colonizado. Sobre a constituição das cidades, denuncia que "[...] dentro delas sempre houve outra cidade, não menos amuralhada, e não menos porém mais agressiva e redentorista, que a regeu e conduziu" (Rama 1985: 42). Tal espaço foi composto por grupos de religiosos, administradores, escritores, educadores, intelectuais, aqueles que tinham o direito de manejar a pena ao ocupar lugares privilegiados de poder. Se a cidade das letras é erigida com base na escrita e por um grupo letrado seleto que, em grande parte, constitui a frondosa burocracia instalada nas cidades a cargo da transmissão de tarefas entre as metrópoles e as sociedades coloniais, é compreensível o porquê das sociedades provenientes de culturas orais, subjugadas como subalternas e inferiores, acabassem por estar de fora do mercado editorial independentista e, portanto, da constituição do cânone literário latino-americano que se instaurava:

Esta palavra escrita viveria na América Latina como a única válida, em oposição à palavra falada que pertencia ao reino do inseguro e do precário. Mais ainda, se pode pensar que a fala procedia da escritura, numa percepção anti-saussuriana. A escritura possuía rigidez e permanência, um modo autônomo que arremedava a eternidade. Estava livre das vicissitudes e das metamorfoses da história, mas sobretudo, consolidava a ordem por sua capacidade de expressá-la rigorosamente ao nível cultural. (Rama 1985: 29-30)

Embora proveniente de culturas de predomínio oral, a comunidade negra conseguiu escalar as muralhas da cidade letrada e deixou, a duras penas, o seu legado. Em Buenos Aires, Casildo Gervasio Thompson se pronunciava como admirador do pan-africanismo, voltando o olhar para 
a África de seus ancestrais. Na Colômbia, Candelario Obeso, em sua curta passagem terrenal, deixou uma valiosa produção literária original ao poetizar o quotidiano da população negra ribeirinha, utilizando a linguagem coloquial, servindo de inspiração para poetas vindouros como Jorge Artel e Nicolás Guillén. Tais escritores não foram considerados canônicos em sua época, no entanto, atualmente, vêm sendo integrados à cidade das letras que os havia excluído por conta das práticas racistas cometidas na formação das nações latino-americanas.

A presente reflexão propõe discutir a relevância de duas obras publicadas nos dois últimos países a abolir a escravidão na América Latina e as estratégias dos autores para narrar a negritude em nações com escravidão ainda institucionalizada. No ano de 1835 , en Cuba, o escravizado Juan Francisco Manzano redige o manuscrito Autobiografía de un esclavo, configurando-se no primeiro texto em prosa de autoria negra na América Latina e o único texto autobiográfico publicado por uma pessoa negra latino-americana; já em Úrsula (1859), Maria Firmina dos Reis surpreende com os escritos abolicionistas de uma mulher negra cuja atitude audaciosa passou por muitos percalços como o de não poder assinar a obra com seu nome, tendo durante muito tempo a autoria atribuída a uma escritora branca de classe média, de outro estado, inclusive. Tratam-se de duas obras vigorosas nas quais é possível constatar, através da escrita de pessoas negras, a invisibilidade às quais foram submetidas, expressada na metáfora da máscara do silenciamento, cuja principal função, segundo Grada Kilomba (2019: 33) era implementar um senso de mudez e medo. Juan Francisco Manzano e Maria Firmina dos Reis, sujeitos conscientes de sua condição, conseguem falar pelos orifícios da máscara ao criarem estratégias narrativas para expressão de sua voz, atuando como cimarrones (Mendes 2019), insurgentes da palavra escrita.

\section{Considerações sobre o gênero romance na América Latina}

O romance é um gênero de escrita que chega tardiamente em terras americanas e seu processo narrativo é descontínuo; segundo Ñíguez Bernal (1987: 43), por um período de três séculos o romance foi considerado um gênero maldito na América hispânica, dado que a Espanha havia proibido terminantemente o envio de textos do gênero a suas colônias pois os inquisidores julgavam que obras como Amadis de Gaula e outras, de qualidade duvidosa, eram perniciosas e subversivas. Para Rama (1982: 49) o romance hispano-americano foi caracterizado, em seus primórdios, como uma arma de combate contra uma ordem estabelecida, geralmente representada no discurso de um personagem irresponsável, marginal ou louco: o exemplo mais conhecido, o Don Quijote de Miguel de Cervantes. Apesar da proibição, não houve como impedir o contrabando de livros de narrativas de cavalaria; no entanto, tal medida acabou por amedrontar os possíveis narradores, que não se animaram a publicar romances até o século XIX. ${ }^{1}$

Somente no final do século o gênero ganha certa autonomia pois, em geral, aos personagens, cenários e temáticas locais é somada uma nova forma literária ajustada à perspectiva das camadas sociais emergentes e o romance se apresenta como o gênero espelho da realidade, simbolizado através do romance de tese que pretendia discutir pontos de vista, denúncias e 
Cadernos de Literatura Comparada

Estratégias cimarronas para narrar a negritude no século XIX

argumentos sobre diversos temas sociais. Doris Sommer sustenta que

Las novelas románticas se desarrollan mano a mano con la historia patriótica en América Latina. Juntas despertaron un ferviente deseo de felicidad doméstica que se desbordó en sueños de prosperidad nacional materializados en proyectos de construcción de naciones que invistieron a las pasiones privadas con objetivos públicos. (Sommer 2004: 23) ${ }^{2}$

O romance latino-americano, desde suas primeiras formulações, esteve acompanhado por aspirações renovadoras que se desenvolvem em um plano utópico, caracterizado pelo compromisso de diálogo com seu tempo e sua sociedade. Sommer (idem: 24) comenta que os romances nacionais do século XIX se transformaram em fontes de história local e orgulho literário em uma época na qual não havia uma clara distinção epistemológica entre arte e ciência, narrativa e fatos, muito menos entre projeções ideais e projetos reais. As fissuras epistemológicas expostas pela história, portanto, foram preenchidas por narradores que projetavam um futuro ideal, tornando, assim, suas obras como romances clássicos de seus respectivos países. Os escritores passaram a ser responsáveis tanto por legitimar o nascimento de uma nação como por impulsionar a história em direção a esse futuro ideal, opinião compartilhada pelo intelectual brasileiro Antonio Candido:

Um traço saliente nas literaturas latino-americanas é o cunho militante do escritor, levando-o com frequência a participar da vida política e dos movimentos sociais, em boa parte porque as condições do meio o empurram neste sentido. (Candido 2001: 264)

A partir das considerações acerca da relevância do gênero romance como formação de pensamento intelectual nas nações latino-americanas, no seguinte subcapítulo será apresentado, de forma panorâmica, o protagonismo de personagens negros nos romances do século XIX publicados na América Latina.

\section{0 protagonismo do personagem negro no romance latino-americano}

Na segunda etapa de pesquisa desenvolvida no Departamento de Línguas Modernas da UFRGS no âmbito do projeto Vozes negras no romance hispano-americano (2016-2017), foi possível analisar oito obras publicadas no século XIX na América hispânica que apresentam protagonistas negros. ${ }^{3}$ Das oito obras, somente uma é de autoria negra: Autobiografía de Juan Francisco Manzano (1835), primeiro (e único de que se tem conhecimento) texto autobiográfico escrito por uma pessoa negra na América Latina ainda no período nefasto de escravização de africanos no continente. Com exceção da autobiografia, os demais textos mantêm as características dos textos românticos: escritos (e lidos) por aqueles que tinham acesso ao letramento (majoritariamente homens, brancos, imigrantes ou criollos de classe média), 4 os escritores registraram as características naturais e sociais das colônias latino-americanas. Em geral, a narrativa costumbrista, para além de ser descritiva, estabelecia 
temáticas sensíveis à sociedade e, portanto, algumas obras foram consideradas romances de tese, textos nos quais os escritores apresentavam temáticas para reflexão e discussão através de uma estrutura discursiva que elucidava o posicionamento dos autores.

Em análises da narrativa dos romances antiescravistas são perceptíveis as estratégias de sobrevivência dos personagens escravizados: há aqueles que se conformam na alienação psicológica, outros que sofrem mais por estarem conscientes das injustiças, como também os que se rebelam violentamente por vingança enquanto outros padecem de forma pacífica. A intenção dos escritores, em maior ou menor grau, era a de denunciar o sistema escravista e o racismo inerente ao mesmo. As obras apresentam tese antiescravista e antirracista segundo o comportamento que desenvolvem os protagonistas negros escravizados e/ou perseguidos. Jeffers (2013) defende a hipótese do romance antiescravista como romance de tese pois, através da temática das violências físicas e psicológicas da escravidão, os autores propõem apontar ao leitor os distintos pontos de vista sobre da forçada submissão africana, denunciando as terríveis atitudes de escravização institucionalizada. Ao questionar o tratamento infligido ao escravizado, humanizam pessoas negras e as evidenciam como seres humanos livres por nascimento, contrapondo-se à sociedade escravista:

La novela antiesclavista es novela de tesis y hay una variedad de textos que utilizan múltiples técnicas para disuadir al lector de las ideas del racismo. Se niega la igualdad de oportunidades del afrodescendiente para vivir y lograr el éxito laboral y personal. El protagonista negro es un personaje de ascendencia negra. En esta definición se incluye el personaje negro, mulato y zambo. El personaje blanco se refiere al que no tiene sangre negra. En Latinoamérica es normalmente descendiente de español en posición de amo. Para observar las modificaciones en este género hacia el ideal del fin del racismo, se tendrán en cuenta dos variables: la caracterización del protagonista negro, a favor o en contra de las formulaciones racistas y la reacción del lector ante el destino merecido o inmerecido del protagonista. La reacción del lector no sólo dependerá de la caracterización del protagonista negro, a favor o en contra de los estereotipos raciales, sino también del destino final del protagonista, a favor o en contra de la integración personal y social del esclavo negro. Dentro de la evolución del género antiesclavista como respuesta del lector al personaje y su destino, se considerará el criterio de la justicia poética, según ésta premie o no la superación del racismo. (Jeffers 2013: 16)

A autora conclui que a limitação de personagens rebeldes na literatura do século XIX se deveu ao medo de rebeliões da crescente população negra, similar ao que havia acontecido no Haiti no fim do século XVIII. Por conta desse fato, a crítica costuma reiterar que a produção literária antiescravista dessa época exibe duas caracterizações opostas para o escravizado, que impedem sua rebelião:

Una consiste en idealizar al protagonista negro como un esclavo perfectamente enamorado e incapaz de rebelarse. En el extremo opuesto, el protagonista pierde la dignidad convertido en fuerza de trabajo impersonal incapaz de tomar conciencia de su condición, por lo que tampoco se rebela. (idem: 20) ${ }^{6}$ 
Cadernos de Literatura Comparada

Estratégias cimarronas para narrar a negritude no século XIX

Os romances publicados no século XIX refletem o contexto racista da sociedade, que não aceitava o matrimônio interracial por dois motivos: racial e econômico. Racial por medo do 'desaparecimento' da raça branca, apagada na figura do mestiço. Econômico, por medo de que as propriedades das elites fossem repartidas em várias famílias, diminuindo o poder dos colonizadores. Por esses motivos, um matrimônio interracial feliz não era possível na ficção, e os finais dessas obras costumam apresentar a morte do personagem negro. Como muitas obras literárias desse período incluem um caso de amor trágico, geralmente entre um homem branco e uma mulher negra ou mestiça, o final para a mulher não podia ser outro se não a morte: "[...] la muerte del esclavo es el castigo de cruzar la línea de clase e intentar el reconocimiento de uno en el otro. El lector normalmente reconoce que el resultado del amor alienante es que el amado conserva el color y el poder." (idem: 25$)^{7}$

Analisando de forma comparativa os discursos empregados nos romances abolicionistas escritos por pessoas brancas às duas obras de autoria negra em questão, é importante destacar a liberdade com que os autores brancos desenvolvem seus argumentos contra a escravidão, fato que não ocorre com os autores negros. Grada Kilomba, em sua obra Memórias da plantação: episódios de racismo cotidiano (2018), resgata a imagem da máscara de Anastácia como a representação do colonialismo como um todo, simbolizando políticas sádicas de conquista e dominação e seus regimes brutais de silenciamento ao questionar: quem pode falar? Sobre o que se pode falar? O que acontece quando falamos?

A boca é um órgão muito especial. Ela simboliza a fala e a enunciação. No âmbito do racismo, a boca se torna o órgão da opressão por excelência, representando o que as/os brancas/os querem - e precisam - controlar e, consequentemente o órgão que, historicamente, tem sido severamente censurado (Kilomba 2018: 33-34)

Por exemplo: a obra Florencio Conde. Escenas de la vida colombiana, de José María Samper (1875), através de protagonistas negros - Segundo e Florencio - discute a construção de nação que se formava ao defender os ideais liberais. Ocupando um espaço de prestígio social, o autor não se eximiu de propor um debate sobre a igualdade de raças e da projeção da mestiçagem como ideal de futuro progressista latino-americano. A obra estabelece o debate sócio-ideológico por meio do texto literário que, segundo intelectuais do século XIX como Samper, acreditavam se tratar do espaço ideal para a educação dos leitores:

Aún hay esclavos en mi patria, pensó un día Florencio, y la raza de mi padre es tiranizada por la de mi madre! No! eso no puede ser, no debe ser! eso es un horrible contrasentido, y mi existencia misma no está en armonía con la vida política de la sociedad a que pertenezco!... Eureka! Ya sé cuál es mi fin, cuál debe ser mi idea fija y el objeto de todos mis desvelos... Dedicaré todo lo que soy y lo que pueda ser al cumplimiento de este propósito: hacer primero que desaparezca totalmente la esclavitud, y procurar luego que el cruzamiento material de nuestras razas se reproduzca en un grande hecho moral: la promiscuidad democrática del gobierno y la justicia cristiana de las leyes (Samper 1875: 158-159) ${ }^{8}$ 
Neste trecho, no qual o autor faz um elogio à mestiçagem, é perceptível que o autor, homem, branco, da elite colombiana, foi autorizado socialmente a criticar a escravidão e, ao compor um protagonista mestiço, coloca em sua boca as ideias liberais que circulavam pelo país no século XIX. O questionamento que se faz é: um escritor negro teria tal autorização? Resposta: pelas (somente) duas obras latino-americanas publicadas por autores negros no século XIX estudadas nesta reflexão, cujos estudos de recepção são ínfimos, não.

A máscara, portanto, levanta muitas questões: por que deve a boca do sujeito negro ser amarrada? Por que ela ou ele tem que ficar calada/o? o que poderia o sujeito negro dizer se ela ou ele não tivesse sua boca tapada? E o que o sujeito branco teria que ouvir? Existe um medo apreensivo de que, se o sujeito colonial falar, a/o colonizadora/o terá que ouvir. Seria forçada/o a entrar em uma confrontação desconfortável com as verdades da/o "Outra/o". Verdades que têm sido negadas, reprimidas, mantidas e guardadas como segredos. (Kilomba 2018: 41)

O romance abolicionista brasileiro Úrsula, curiosamente, ao contrário das oito obras hispânicas, que apresentam em seus títulos os nomes dos/as protagonistas negros/as, revela uma protagonista branca e, em uma leitura superficial, o enredo trata de amor, dor, incesto e morte - temáticas comuns do romantismo - entre Úrsula e seus pretendentes, Tancredo e seu tio, o comendador Fernando P. Maria Firmina, mulher, negra e habitante de uma região brasileira conservadora, distanciada dos grandes centros econômicos e culturais da época (Rio de Janeiro e São Paulo) e herdeira da cultura da plantação de cana de açúcar, desenvolveu estratégias de escrita para falar sobre o que realmente importava: o tratamento concedido a pessoas escravizadas (a escravidão foi abolida somente em 1888, como parte da mudança política do país de Império a República em 1889). A autora constrói personagens negros conscientes de sua condição e conhecedores de sua cultura e de seu passado africano, algo inédito de ser encontrado na literatura brasileira do século XIX.

A Autobiografia de Juan Francisco Manzano, embora classificada como gênero testemunho, está incluída no corpus de análise por se tratar de uma narrativa longa do século XIX, época em que os gêneros literários ainda não haviam sido nitidamente definidos. O processo de escritura da obra foi permeado por diversas problemáticas: pelo fato do autor ainda estar em situação de escravização, e de escrever em troca de sua liberdade, encontrava-se em uma encruzilhada, pois, por um lado, para descrever os horrores da escravidão, era necessário que ele falasse sobre as violências sofridas; por outro lado, como seus donos ainda estavam vivos, existia uma óbvia limitação do que poderia ser dito sobre eles. Mesmo críticos da escravidão, os intelectuais abolicionistas não queriam ouvir tudo o que Manzano tinha para dizer posto que deveriam se confrontar com todo o sistema de opressão do qual eles faziam parte como opressores. Nesse sentido, a obra que chega ao grande público é uma ficção, pois o texto passou por muitas correções e alterações para que fosse digerível ao grupo leitor. No entanto, é admirável a forma com que Manzano consegue tangenciar o foco principal - descrição das torturas - apresentando-se como um grande escritor latino-americano. 
Cadernos de Literatura Comparada

Estratégias cimarronas para narrar a negritude no século XIX

\section{Autobiografia de um poeta cimarrón: o relato de Juan Francisco Manzano}

Contrariamente às Américas hispânica e portuguesa, que não cultivaram a tradição abolicionista de incentivo à escrita e publicação de pessoas recentemente saídas da condição de escravizadas, nos Estados Unidos tal tradição deixou atualmente em torno de 101 memórias de escravizados publicadas até o ano de 1865 (Castro 2015). As narrativas de escravizados que surgiram no século XIX abraçaram a dupla missão de denunciar as mazelas do sistema escravocrata e, ao mesmo tempo, subverter e revisar o discurso político-teológico vigente. Com teor diverso, passando desde a história de pessoas trazidas da África até pessoas nascidas na América, algumas são bastante conhecidas do público leitor latino-americano: Narrative of the life of Frederick Douglass, an American Slave, de Frederick Douglass (1845); Incidents of the life of a slave girl (1861), de Harriet Jacobs (sob o pseudônimo de Linda Brent); Narrative of Sojourner Truth: a northern slave, de Sojourner Truth; e, talvez, o texto mais conhecido internacionalmente, Twelve years a slave (1853), de Solomon Northup, adaptado ao cinema em 2013 e ganhador do Oscar de melhor filme em 2014.

Percebe-se, portanto, que na tradição literária estadunidense, as slave narratives constituem um gênero literário importante. Na América Latina, além da autobiografia de Manzano, há registros de outras duas obras similares, porém não inteiramente iguais: Biografia de un cimarrón (1966), redigida pelo antropólogo cubano Miguel Barnet a partir das histórias de Esteban Montejo, ex-escravizado de 108 anos e Biografia de Mahommah Gardo Baquaqua (1854), publicada pelo abolicionista Samuel Moore, cujo relato perpassa a vida de Baquaqua, escravizado africano que esteve parte de sua vida em território brasileiro. Kerchner (2018:12) aponta que a publicação inicial do livro foi repleta de problemáticas. Após entrega do manuscrito da Autobiografia em 1835, este foi imediatamente traduzido ao inglês por Richard Madden e publicado na Inglaterra em 1840 sob o título Poems by a Slave in the Island of Cuba, Recently Liberated; Translated from the Spanish, by R. R. Madden, M.D. With the History of the Early Life of the Negro Poet, Written by Himself; to Which Are Prefixed Two Pieces Descriptive of Cuban Slavery and the Slave-Traffic, by R. R. M. [Poemas por um escravo na ilha de Cuba, recentemente liberado; traduzido do espanhol por R. R. Madden, M. D. com a história da vida inicial do poeta negro, escrita por ele mesmo; a qual está precedida por dois quadros descritivos da escravidão de Cuba e o tráfico de escravos, por R. R. M.]. Somente em 1937 o texto seria publicado em espanhol em Cuba e apenas em 2015 o público leitor brasileiro ganha uma tradução comentada em português, fato que revela que a obra é muito mais conhecida e estudada no mundo anglófono que no hispano-americano e, menos ainda, no brasileiro. Para além dessas observações, é possível notar que não há menção ao nome de Manzano na tradução em inglês, que apresenta o autor como "um escravo da ilha de Cuba", apagando totalmente sua individualidade ao inseri-lo em um coletivo exótico - negro, escravizado e poeta. Somado a este fato, Madden efetuou diversas modificações no texto ao ocultar trechos inteiros, principalmente os que diziam respeito à subjetividade do autor, criando uma imagem do escravizado e das pessoas que o circundavam, transformando o texto que acaba servindo, portanto, aos seus interesses como abolicionista. 
De acordo com Ramos (2017) a literatura cubana de temática escravagista desenvolvida no século XIX era, em grande parte, publicada a partir de encomendas vindas da Europa realizadas por intelectuais como Domingo del Monte, crítico literário e fundador da Academia Cubana de Literatura. Para Del Monte e os demais ideólogos abolicionistas, altamente influenciados pelos ideais estadunidenses e ingleses, a criação de tertúlias possibilitava a discussão sobre a temática e, nesse contexto, Juan Francisco Manzano, conhecido por declamar seus poemas em reuniões e saraus poéticos, é convidado a escrever a sua história. No entanto, para Alex Castro, tradutor e comentarista da obra para o português brasileiro (Autobiografia do poeta-escravo Juan Francisco Manzano, 2015), o convite não surgiu apenas pela admiração que os participantes sentiam por sua oratória: é importante lembrar que, nessa época, os ventos da revolução haitiana ainda se moviam pelas colônias e a encomenda do texto se inseriu no projeto de desviar o olhar do temido "perigo negro" e mostrar aos interessados no tema um escravizado submisso, religioso e obediente que seguia os códigos sociais brancos. Além da Autobiografia, Manzano também publicou um livro de poemas, Flores pasajeras (1830) e uma peça dramática, Zafira (1842). Acusado de ter participado da Conspiración de la Escalera, em 1844, ficou preso por um ano e, após o fuzilamento de outros poetas negros acusados de conspiradores, passou seus últimos anos sem escrever, talvez por se dar conta de que estar em evidência literária poderia ser sua condenação.

A existência do texto de Manzano é insólita para a época, já que a maioria dos escravizados era analfabeta, com qualquer acesso ao letramento vedado pelos proprietários. Manzano se apropria do proibido, aprendendo a ler e escrever escondido, desenvolvendo sua veia poética e conquistando seu público ouvinte/leitor até se tornar protegido de Del Monte e ser convidado a escrever sua história de vida em troca da liberdade. E é justamente por esse motivo, por ter um padrinho dentro do mais respeitado círculo literário de Cuba, adjunto ao fato de que homens da elite cubana - incluindo seu dono - também participavam dos saraus, que é possível notar uma clara ponderação em seus relatos, principalmente quando se refere à sua ama, a Marquesa del Prado Ameno. Castro afirma que a Autobiografia não é prosa espontânea já que houve reflexão, escolha de episódios e construção narrativa:

\footnotetext{
Para Manzano, então ainda escravizado, a redação de sua autobiografia foi um empreendimento temerário, repleto de dificuldades práticas e políticas. O quanto falar? O quanto silenciar? O quanto aqueles homens brancos e ricos, aparentemente tão tolerantes, eram capazes de ouvir e silenciar? Sua autobiografia é um texto de lacunas gritantes, elipses conspícuas, entrelinhas prolixas. É necessária uma leitura cuidadosa para decifrar seus silêncios. (Castro 2015: 16)
}

Continuamente, Manzano menciona episódios que decide não contar: "[...] estive a pique de perder a vida em maõs do sitado Silbestre mas passemos em silencio o resto d'esta sena doloroza pasado este tempo com otra multidaõ de acontecimentos semeliantes [...]" (Manzano 2015:107). ${ }^{9}$ Castro expõe em nota: "Em Manzano, todo clímax é seguido de um silêncio ainda mais estrondoso, um silêncio intencional que simultaneamente revela e ofusca" (Castro 2015: 
162). Além dos silêncios, o tradutor também analisa as rasuras do manuscrito: "No manuscrito, depois de 'mas', Manzano escreveu 'a última', rasurou e substituiu por 'a vez pa. mim mais memorável qe. todas'. Quantas cenas terríveis de tortura e castigo Manzano não deveria estar equilibrando em sua memória para fazer esse tipo de autocorreção?" (ibidem).

Para Kerchner (2018: 39), Manzano estava plenamente consciente de sua condição subalternizada, do lugar do qual falava, do quanto seu discurso era desprestigiado e do quanto ele não tinha autorização para falar o que desejava. No trecho "[...] sei que nunca serei considerado hum homem imparsial se verá até qe. ponto xega a prevensaõ do maior numero dos homem contra o infeliz qe. incorreto nalguma fraqueza" (Manzano 2015: 115), se entende que o poeta teme o julgamento de seu leitor, que o considere culpado de alguma das situações descritas. Dessa forma, em diversos momentos, narra as torturas partindo do motivo do castigo, sempre desproporcionais a qualquer travessura que uma criança ou um adolescente pudesse haver cometido: "Novamente, deparamo-nos com o processo de recusa: não eram os escravistas que infligiram a seus escravizados penas duras, mas eles que pediam por esse castigo, ao não obedecerem cegamente às suas ordens." (Kerchner, idem).

A Autobiografia, embora escrita por um escravizado cubano que relata suas vivências de forma pontual em Havana e Matanzas, representa a vida do escravizado enquanto cativo na América colonial, com todas as suas proibições e violências acometidas. Da mesma forma, se trata de uma história individual, de um homem que superou barreiras para aprender a ler e a escrever por conta de sua paixão pela poesia, gênero que despertou sua sensibilidade para o texto literário, mesmo vivendo em condições sub-humanas. Trata-se, portanto, de uma narrativa essencial na história da literatura latino-americana, que deveria constar bibliografia básica nos currículos dos cursos de Literatura das universidades hispânicas como também nos cursos de Letras-Espanhol das universidades brasileiras.

\section{Maria Firmina dos Reis, uma cimarrona brasileira}

A história "real" da escritora Maria Firmina dos Reis (São Luís, 1822-1917) é praticamente uma ficção, começando pelas controvérsias sobre sua imagem. Ao assinar a obra Úrsula como "Uma maranhense", somente na década de 1970, quando seu biógrafo procurou a fundo informações com seus alunos já nonagenários, foi possível saber que se tratava de uma mulher negra. Até aquele momento a imagem de Maria Firmina era representada pela da escritora Maria Benedita Câmara Borman (1853-1895), conhecida como Delia, através de um quadro pintado e doado anonimamente a um edifício administrativo da cidade de Guimarães, no mesmo estado. Da mesma forma, o busto feito por Flory Gama em sua homenagem na Praça do Panteon Maranhense a projeta com nariz afilado, lábios também finos, cabelo liso, em nada referenciada como uma mulher negra ou mulata (Silva 2013: 96). Até os dias de hoje, não foi possível encontrar nenhum documento no qual houvesse registro de sua verdadeira imagem:

Após a imagem da primeira mulher negra romancista, criada nos anos 70, e retomada nos anos 80, no centenário da abolição, em 1988 é publicada a terceira edição de Úrsula, em que se constrói a imagem 
de Maria Firmina dos Reis abolicionista. A partir de então, a crítica literária tomou Maria Firmina como uma escritora abolicionista, e por isso deveria ser respeitada. Pioneira, negra, mulher e abolicionista. (Silva 2013: 97)

Pedroso (2018: 8) comenta que devido à localização de documentos no Maranhão, duas informações referentes à sua biografia foram corrigidas. A primeira é sobre sua data de nascimento: inicialmente definida em 11 de outubro de 1825, recentemente se descobriu que esta havia sido a data de seu batismo e que ela havia nascido em 11 de março de 1822. A segunda é com relação à sua filiação: foi a primeira filha de João Pedro Esteves e Leonor Felipa dos Reis, que nunca se casaram oficialmente. Pesquisas anteriores revelam que o pai era negro e a mãe, branca, da família Reis, muito extensa na cidade de Guimarães, uma comunidade do litoral do Maranhão, e bem colocada socialmente, embora não rica. Com a descoberta de tais documentos, no Auto de Batismo de Firmina, percebe-se a indicação de sua mãe como mulata, o que confirmaria sua identificação como mulher negra. Seja qual for sua verdadeira história de vida, sua origem a destinava ao silêncio já que ocupava um espaço nada acolhedor para uma mulher negra, bastarda e de família de poucas posses numa sociedade escravista, conservadora e patriarcal. Contra todas as expectativas, conseguiu ocupar áreas excludentes para alguém de sua condição (Machado 2019). Para Pedroso (2018: 9), os aspectos biográficos de Firmina merecem crédito porque fazem parte de uma história em processo de descoberta e apresentada muitas vezes de forma equivocada, como o caso da representação branca da autora.

A partir da publicação de Úrsula em jornal do Maranhão, foram abertas oportunidades para a divulgação de seus outros escritos: Cantos à beira-mar (poemas, 1871), Gupeva (conto, 1881) e A Escrava (conto, 1887). Em 1880 foi credenciada como professora e, no mesmo ano, entra para a história da educação brasileira por fundar uma das primeiras escolas mistas do país, destinada a filhos e filhas de trabalhadores das fazendas, muitos ainda em situação de escravizados, motivo pelo qual, provavelmente, segundo Pedroso (ibidem) a escola tenha sido fechada dois anos depois por ordem do governo. Já aposentada, segue ensinando para filhos e filhas dos camponeses e das lavandeiras.

Úrsula permaneceu esquecida até o ano de 1962 quando o historiador Horacio de Almeida encontra um exemplar do livro em um sebo e põe a escritora em evidência. Chama a atenção o texto assinado como "Uma maranhense" e logo se descobre que se trata do único exemplar de publicação original da obra. Segundo Machado (2019) o Brasil possui uma literatura abolicionista peculiar que se caracteriza por ter surgido tardiamente. Na literatura anterior a 1850, os personagens negros eram escassos e, quando apareciam, estavam no papel de escravizados e sua confecção se resumia a atitudes superficiais e distantes; um elemento a mais na paisagem das descrições costumbristas. A grande presença da população africana e afrodescendente no Brasil, escravizada ou liberta, não encontrava contrapartida: nenhum personagem negro apresentaba um crescimento capaz de captar a atenção ou se tornar o foco da narrativa. Depois de 1850, a literatura romântica brasileira começa a apresentar escravizados e escravizadas com mais densidade dramática mas com personagens estereotipados como a escravizada branca, 
Cadernos de Literatura Comparada

Estratégias cimarronas para narrar a negritude no século XIX

bela e pura (A escrava Isaura, de Bernardo Guimarães, 1875), o malandro muito esperto e a mulata sensual (O cortiço, de Aluísio de Azevedo, 1890), o escravizado violento e vingativo (As vítimas-algozes, de Joaquim Manoel de Macedo, 1869) como também o negro vítima (Os escravos, de Castro Alves, 1883). Percebe-se uma literatura no qual o/a escravizado/a era descrito ou como vítima absoluta ou como personagem maléfico, de caráter e de personalidade disfuncional produzidos pela miséria do sistema escravista: "As mazelas da escravidão, nesse sentido, recaíam especialmente nos afrodescendentes, que acabavam recebendo finais trágicos e eram, com razão, expurgados da cena literária - que, obviamente, surgia como metáfora para purificação da sociedade" (Machado 2019: par. 3).

A narrativa conta a história da jovem Úrsula que é presa por seu tio, provável assassino de seu pai e usurpador de suas propriedades, fato que a atormentará por todo o romance, ainda mais porque tal tio tem o desejo de se casar com ela e se desloca como uma sombra do mal em sua vida. Sua mãe está doente e dependente dela; seu grande amor, Tancredo, é assassinado pelo mesmo tio sem caráter. A escravidão é o cenário social e predominam as relações de dominação entre senhores e escravizados. Maria Firmina dos Reis rompe com a tradição romântica brasileira de apresentar personagens negros como parte da paisagem e, efetivamente, concede a eles a voz no texto literário. O capítulo IX, intitulado A preta Susana, apresenta o diálogo entre esta, africana capturada em seu país, e Tulio, escravizado que é amigo do branco protagonista Tancredo - por tê-lo salvado da morte logo no início da narrativa. Tulio, ao afirmar que é livre (Reis 2018: 103), pois tem autorização para viajar com Tancredo, escuta o questionamento da senhora sobre o conceito de liberdade defendido pelo rapaz ao regressar às suas memórias de quando vivia em seu povo com sua família no continente de onde foi levada pelos "bárbaros", definindo o que era a verdadeira liberdade: "Tudo me obrigaram os bárbaros a deixar! Oh, tudo, tudo até a própria liberdade" (idem: 104). Narra as crueldades do tráfico (a captura, o distanciamento da família, os trinta dias de viagem no navio negreiro nomeado como uma sepultura, a falta de condições básicas de higiene e alimentação, as mortes dos companheiros de infortúnio):

A dor da perda da pátria, dos entes caros, da liberdade fora sufocada nessa viagem pelo horror constante de tamanhas atrocidades. Não sei ainda como resisti - é que Deus quis poupar-me para provar a paciência de sua serva com novos tormentos que aqui me aguardavam. (idem: 106 107)

Apesar de Maria Firmina ter sido conterrânea e contemporânea de grandes nomes da literatura brasileira como Gonçalves Dias (1823-1864), Aluísio de Azevedo (1857-1913) e Sousandrade (1833-1902), não foi reconhecida nacionalmente como escritora (Pedroso 2018: 10) e, se não fosse pela descoberta do exemplar de Úrsula por Horacio de Almeida, ainda estaria na invisibilidade. Para Monteiro (2019: 362), Maria Firmina desconstrói uma história literária etnocêntrica e masculina até mesmo em suas ramificações afrodescendentes pois, além de ser a primeira obra publicada por uma pessoa negra no Brasil, traz a temática da negritude a partir de uma perspectiva interna e comprometida politicamente em discutir a condição dos negros no país inaugurando, dessa forma, o momento no qual descendentes de escraviza- 
dos escrevem a história com suas próprias mãos, projetando através da literatura o desejo de construir um país sem opressões.

\section{Juan Francisco Manzano e Maria Firmina dos Reis no século XXI: leituras possíveis da cimarronagem}

O pesquisador Rogerio Mendes defende, em 2019, tese de doutorado conceitualizando a pedagogia da cimarronagem. Segundo Mendes (2019: 25), a palavra cimarrón era utilizada por senhores de escravizados oligarcas em tempos coloniais para se referirem aos escravizados que escapavam de suas propriedades. Os cimarrones recorriam à fuga não somente para desfrutar de sua liberdade mas sim para exercer os valores cosmogônicos que os definiam como indivíduos e cultura, em sua completude. As pedagogias da cimarronagem são definidas como atitudes, estratégias e metodologias desenvolvidas através de ações e práticas humanas afrodescendentes interessadas na autonomia, na liberdade e no reconhecimento de seus valores:

O cimarrón é apresentado no estudo como um personagem-conceitual que opera insurgências individuais e coletivas na representação e valorização das cosmogonias e cosmovisões afrodescendentes. Ele se apresenta onisciente e onipresente, herança viva de tradições, linguagens e saberes em permanente dinâmica de cruzo. No texto manifesta-se como Orixás; Inquices; escravizados; personagens históricos e ficcionais; conceitos; mitos; poetas; ensaístas; críticos literários; sociólogos, músicos e epistemologias mencionadas ao longo da tese. Pode-se dizer que o cimarrón é sentimento, representação e patrimônio de uma ancestralidade continuamente operante e difusa que desafia as lógicas disciplinares e civilizacionais instauradas historicamente à revelia de sua origem e realidade. Observa-se, dessa maneira, pela natureza cimarrón, que ele representa a africanidade em sua essência. (Mendes 2019: 28)

Considera-se, portanto, que Juan Francisco Manzano e Maria Firmina dos Reis foram cimarrones da palavra escrita na literatura latino-americana pois, embora com suas bocas seladas, desenvolveram estratégias narrativas que revelam muito sobre o período escravagista nas Américas: Manzano, escravizado, semi-analfabeto, copista de poemas, cria um texto em prosa do qual não havia modelos a serem copiados, falando o que os leitores brancos queriam ouvir e, ao mesmo tempo, identificando em seus silêncios e suas confusões cronológicas uma outra história contada nas entrelinhas, demonstrando-se astuto, irônico e inteligente em suas palavras; Maria Firmina, negra liberta quando ainda havia escravidão institucionalizada no Brasil, uma cimarrona por sua atuação social, por defender uma educação libertadora para meninos e meninas, por ocupar um espaço negado às mulheres no século XIX, por ter conseguido publicar um romance quase 30 anos antes da abolição da escravidão no país, criando uma narrativa que traz uma história de amor entre um casal branco como protagonista mas que, como Manzano, conta uma outra história nas entrelinhas, utilizando-se do registro escrito para eternizar seu posicionamento com relação às agruras da escravidão.

Para Castro (2015), as poesias publicadas por Manzano chamaram a atenção pela imitação do estilo neoclássico desenvolvido pelos literatos, alcançando o domínio do estilo pois 
suas poesias são, praticamente, paródias daquelas escritas por pessoas brancas, graças ao seu gênio para imitação e seu talento transgressor mimético. No entanto, a genialidade do autor está justamente na escritura da Autobiografia, gênero sem pessoas autobiográficas para imitar e/ou parodiar e sem personagens para se inspirar. Quando se trata do gênero testemunho, curiosamente, um dos livros cubanos mais conhecidos e traduzidos é justamente Memorias de un cimarrón, de Miguel Barnet: a história de Esteban Montejo correu o mundo e acabou sendo referência ao se falar sobre a escravidão na ilha, visto que os revolucionários de 1959 o "escolhem" por seu espírito inquieto e insatisfeito com a situação, ao contrário de Manzano, demasiado "manso" e "conservador". Nota-se, dessa forma, o quanto o texto foi menosprezado e reduzido a um simples relato da situação de escravidão de alguém que, ao ser um escravizado da casa grande, se apropriou dos conhecimentos que adquiria e assumiu uma postura de aculturação como estratégia de sobrevivência. Manzano pode não ter sido um cimarrón no sentido estrito do termo, porém, a escrita poética reflete sua insubordinação:

[...] mas como a melancholia estava ja instalada em minh'alma e avia tomado em meu phyzico huma parte de minha ezistencia eu me alegrava em baixo de uma guaxiúma cujas rahizes formava huma especie de pedestal onde eu pescava compondo alguns versos de memoria e todos eraõ sempre tristes os coaes eu naõ escrevia por ignorar esse ramo p. isto sempre trazia hum caderno de versos de memoria e por coalquer couza improvizava [...] (Manzano 2015: 101)

Como característica de grande parte dos romances do século XIX, o autor e/ou narrador está consciente da interlocução e, inclusive, faz referências ao fato, convidando a pessoa leitora a acompanhar o desenvolvimento da narrativa, por vezes provocando questionamentos. Maria Firmina assina o prólogo da obra que, lembrando, não revelava a autoria:

Mesquinho e humilde livro é este que vos apresento, leitor [...] Sei que pouco vale este romance, porque escrito por uma mulher, e mulher brasileira, de educação acanhada e sem o trato e a conversação dos homens ilustrados que aconselham, que discutem e que corrigem, com uma instrução misérrima, apenas conhecendo a língua de seus pais, e pouco lida, o seu cabedal intelectual é quase nulo. Então por que publicas?, perguntará o leitor. (Reis 2018: 5)

Para Pedroso (2018: 8) é provável que o prólogo fosse um subterfúgio linguístico de sofisticada ironia de uma mulher que conhecia muito bem o seu espaço social e o de seus prováveis leitores; o texto já anunciava que estaria na contramão dos romances publicados no período: "O nosso romance, gerou-o a imaginação, e não o soube colorir, nem aformosentar" (ibidem). Interessa a afirmação da autora ao dizer que não soube "colorir" nem "enfeitar" uma história de violência, racismo e preconceito, algo que os demais autores de romances abolicionistas homens brancos - fizeram com êxito, sendo reconhecidos como grandes escritores, constando nos cânones literários das nações latino-americanas. 
Se o romance foi o gênero literário responsável por projetar os ideais de nação, por que um romance escrito por uma mulher negra que discute, justamente, a questão racial, não teve visibilidade em seu país? Por que o relato autobiográfico de um poeta escravizado semi-alfabetizado somente foi publicado em seu país praticamente cem anos após sua escrita? Por que às pessoas negras não lhes foi permitido ocupar os espaços intelectuais? Por que às pessoas negras não houve a possibilidade de projetar e participar dos debates de construção das jovens nações? Por que a veia poética de Juan Francisco Manzano foi excluida de seu texto final? Por qual motivo Maria Firmina dos Reis não pode assinar sua obra? Essas perguntas, das quais é possível inferir as respostas, confirmam a concepção de sociedades patriarcais, machistas e racistas que, no âmbito literário, se mantêm até os dias de hoje. Conforme pesquisa da professora Regina Dalcastagnè, da Universidade de Brasília (UnB), com resultados publicados em 2018 na Revista Cult, ao analisar 692 romances de 383 autores publicados em distintos momentos (1965-1979; 1990-2004 y 2005-2014), as conclusões apresentadas demonstram o perfil do escritor brasileiro: homem, branco, de classe média, do centro Rio de Janeiro-São Paulo. Seus narradores, personagens protagonistas e secundários são homens, brancos, de classe média, heterosexuais e moradores de grandes cidades. O que chama a atenção, mas não surpreende, é a falta de mulheres e homens negros tanto na posição de autores ( $2 \%$ ) como de personagens (6\%); mulheres negras aparecem como protagonistas em somente seis obras e, em outras duas, como narradoras. A título de comparação, mulheres brancas, por sua vez, ocuparam essas posições 136 e 44 vezes, respectivamente. A pesquisa comprova a dificuldade de acesso das mulheres negras na formação do espaço literário brasileiro. Dalcastagné (par. 4) atribui o desequilíbrio ao próprio mercado literário que produz um círculo vicioso de publicações homogêneas escritas a partir de um ponto de vista de uma classe média autorreferente e entediante:

Quando as grandes editoras publicam livros que tratam sempre dos mesmos temas e trazem um perfil de autor muito parecido, estão dizendo ao leitor o que é considerado literatura e quem pode ser chamado de escritor no Brasil. (Dalcastagné, ctd em Massuela, par. 4) ${ }^{10}$

Através da arte da literatura é possível criar imagens emotivas por meio da revelação de experiências íntimas ao traduzir o sentimento e o pensamento e transmitir, nesse processo, a profundidade da experiência humana, do ser/estar no mundo de mulheres e homens. A escrita, com suas metáforas, alegorias e discursos retóricos delimita o espaço social como terreno no qual os seres humanos atuam, pois a realidade é constantemente recriada por um processo cíclico de articulação, desarticulação e rearticulação. Maria Firmina dos Reis fez sua passagem em 11 de novembro de 1917, cega e pobre. Triste fim para uma das poucas mulheres negras abolicionistas da América Latina que conseguiu publicar um romance, alcançando o patamar da escrita literária dos homens de classe média, filhos de senhores de escravizados, que iam à Europa para estudos e regressavam com os ideais progressistas e liberais. Quanto a Juan Francisco Manzano, as datas de seu nascimento e morte são imprecisas, como muitos fatos 
Cadernos de Literatura Comparada

Estratégias cimarronas para narrar a negritude no século XIX

de sua vida. No entanto, seu nome permanece na história literária da América Latina como o primeiro texto autobiográfico publicado e único escrito por uma pessoa negra em situação de escravização.

Como possibilidade de revisitar o cânone literário latino-americano, as duas obras analisadas devem constar nas bibliografias das universidades e escolas de educação básica latino-americanas na intenção de resgatar a vitalidade dos textos produzidos no século XIX por pessoas que foram excluídas da cidade letrada e que, de muitas formas, revelam a perversão das elites que apregoavam o discurso abolicionista mas não foram capazes de decodificar e difundir os textos escritos pelos maiores interessados na abolição da escravidão. Mesmo na contracorrente do sistema - e com um toque de sorte - as obras permaneceram, configurando-se em registros documentais da época, assim como o foram as ficções de fundação canônicas. Nesse sentido, e com toda a admiração pelos escritores Manzano e Maria Firmina, as duas obras debatidas confirmam as palavras de Tulio, personagem de Úrsula: "Oh, a mente! Isso sim ninguém a pode escravizar!" (Reis 2018: 31)

\section{NOTAS}

* Liliam Ramos é professora do quadro permanente do Programa de Pós-Graduação em Letras da Universidade Federal do Rio Grande do Sul (UFRGS), Brasil, e atua nas linhas de pesquisa 1. Pós-colonialismo e identidades e 2. Sociedade, (inter)textos literários e tradução nas literaturas estrangeiras modernas. É mestre em Letras - Literatura Comparada e Doutora em Letras Literaturas Estrangeiras Modernas (espanhol) pela UFRGS e especialista em ensino de língua e literatura espanhola pela PUCRS. Atuou como professora visitante com bolsa CAPES na Universidade de Cartagena, Colômbia, de março a novembro/2020 onde ofertou a disciplina Introdução à língua e à literatura brasileiras. Tem publicações nas áreas de tradução decolonial e literatura latino-americana de autoria negra. Coordena o projeto de pesquisa Literatura Afro-latino-americana (2019-2021) e oferta a disciplina na graduação e pós-graduação, abertas também via extensão universitária.

\footnotetext{
${ }^{1}$ A referência ao primeiro romance histórico publicado na América Latina é Xicotencátl (1826), de edição anônima, logo atribuída ao mexicano Salvador García Bahamonte na segunda edição publicada em 1871 em Valência, Espanha (Ramos 2015: 78). 2 "Os romances românticos se desenvolvem passo a passo com a história patriótica da América Latina. Juntos, despertaram um fervente desejo de felicidade doméstica que transbordou em sonhos de prosperidade nacional materializados em projetos de construção de nações que investiram nas paixões privadas com objetivos públicos" (tradução nossa).

3 Doravante, sempre que as referências forem direcionadas ao citado romance, a expressão virá em itálico (O Magriço). Quando não grafada assim, ela se refere ao protagonista homônimo (Álvaro Gonçalves Coutinho - o Magriço), personagem principal da obra em análise.

${ }^{3}$ As obras são: Autobiografía de Juan Francisco Manzano (1835); Petrona y Rosalía (1838), de Félix Tanco y Bosmeniel (Cuba);
} 
Francisco, el ingenio o las delicias del campo (1840), de Anselmo Suárez y Romero (Cuba); Sab (1841), de Gertrudis Gómez de Avellaneda (Cuba); Florencio Conde: escenas de la vida colombiana (1875), de José María Samper (Colômbia); El negro Francisco: novela de costumbres cubanas (1880), de Antonio Zambrana y Vázquez (Cuba); Cecilia Valdés o la loma del ángel (1882), de Cirilo Villaverde (Cuba) y Roque Moreno (1899), de Teresa González de Fanning (Perú).

4É interessante destacar a obra Sab (1841), escrita por Gertrudis Gómez de Avellaneda, que em sua condição de mulher na colônia, se identificava com a situação dos escravizados ao sentir a indiferença dos estrangeiros e criollos em relação às mulheres bem como aos africanos e afrodescendentes (Ramos 2015: 86).

5 "O romance antiescravista é romance de tese e há uma variedade de textos que utilizam técnicas múltiplas para dissuadir o leitor das ideias do racismo. É negada ao afrodescendente a igualdade de oportunidades para viver e atingir o êxito laboral e pessoal. O protagonista negro é um personagem de ascendência negra. Nessa definição, é incluído o personagem negro, mulato e zambo. O personagem branco é aquele que não tem sangue negro. Na América Latina, normalmente é o descendente de espanhol em posição de amo. Para observar as modificações neste gênero com o objetivo de findar o racismo, se levará em conta duas variáveis: a caracterização do protagonista negro, a favor ou contra das formulações racistas e a reação do leitor diante do destino merecido ou não merecido do protagonista. A reação do leitor não somente dependerá da caracterização do protagonista negro, a favor ou contra dos estereótipos raciais, como também do destino final do protagonista, a favor ou contra da integração pessoal e social do escravizado negro. Na evolução do gênero antiescravista como resposta do leitor ao personagem e seu destino, será considerado o critério da justiça poética, segundo esta contemple ou não a superação do racismo" (tradução nossa).

6 "Uma consiste em idealizar o protagonista negro como um escravizado totalmente apaixonado e incapaz de se rebelar. No extremo oposto, o protagonista perde a dignidade convertido em força de trabalho impessoal, incapaz de tomar consciência de sua condição, motivo pelo qual tampouco se rebela" (tradução nossa).

7 "[...] a morte do escravizado é o castigo de cruzar a linha de classe e tentar o reconhecimento no outro. O leitor normalmente reconhece que o resultado do amor alienante é que o amado conserva a cor e o poder" (tradução nossa).

8 "Ainda há escravizados na minha pátria, pensou um dia Florencio, e a raça de meu pai é tiranizada pela da minha mãe! Não! Isso não pode acontecer, não deve acontecer! Isso é um horrível contrassenso, e minha existência mesma não está em harmonia com a vida política da sociedade a qual pertenço!... Eureka! Já sei qual é o meu fim, qual deve ser minha ideia fixa e o objetivo de todos meus cuidados... Dedicarei tudo o que sou e o que puder ser ao cumprimento desse propósito: fazer primeiro com que desapareça totalmente a escravidão, e procurar logo que o cruzamento material de nossas raças se reproduza em uma grande façanha moral: a promiscuidade democrática do governo e a justiça cristã das leis" (tradução nossa).

${ }^{9}$ É necessário destacar o primor com que Alex Castro realiza a tradução da Autobiografia para o português brasileiro. A edição traduzida divide-se em 3 partes: primeira, prefácio de Ricardo Salles, professor no curso de História da UNIRIO, especialista em século XIX; a segunda, dois trabalhos de transposição à língua portuguesa - uma tradução (texto quebrado em parágrafos, atualização de pontuação e ortografia, simplificação de orações truncadas e substituição de vocábulos fora de uso - tudo isso como exigência da editora) e um surpreendente trabalho de transcriação (criação da voz de um Manzano lusófono fictício, dando fidelidade à voz do escravizado, à sua sintaxe, à sua escolha de palavras, ao ritmo das frases e à sua peculiar pontuação, mantendo os desvios da norma culta em português na mesma proporção do espanhol escrito por ele em 1835) e, a terceira, onde o leitor é brindado com iconografias, sugestões de leituras e mais de 300 notas explicativas sobre o texto de Manzano. Na presente reflexão, as citações retiradas do texto autobiográfico de Manzano seguirão as normas da transcriação elaborada por Castro, no intuito de manter o respeito e a admiração pelo poeta que tentaram calar por tantas vezes.

${ }^{10}$ A pesquisa foi realizada com os três maiores grupos editoriais do Brasil: Record, Companhia das Letras e Rocco. 
Cadernos de Literatura Comparada

Estratégias cimarronas para narrar a negritude no século XIX

Bibliografia

Alves, Castro (1944), "Os escravos", Obras completas de Castro Alves, Rio de Janeiro, Companhia Editora Nacional.

Azevedo, Aluísio de (1890), o cortiço, Rio de Janeiro, B.L.Garnier.

Candido, Antonio (2001), "Uma visão latino-americana" in Chiappini, Lígia/ Aguiar, Flávio Wolf de (org), Literatura e história na América Latina, São Paulo, EDUSP: 263-269.

Castro, Alex (2015), Autobiografia do poeta-escravo Juan Francisco Manzano. Organização, tradução e notas de Alex Castro. Rio de Janeiro, Hedra [1835].

Guimarães, Bernardo (1875), A escrava Isaura, Rio de Janeiro, B.L.Garnier.

Gómez de Avellandeda, Gertrudis (1920), Sab, Buenos Aires. Agencia Nacional de Librería.

Jeffers, Nydia (2013), El protagonista negro en la narrativa antiesclavista latinoamericana del siglo XIX, Tese de Doutorado. Department of Languages and Literatures da University of Nebraska, Lincoln. <https://digitalcommons.unl.edu/modlangdiss/17/> (último acesso em 14/08/2020)

Kerchner, Adriana (2018), Juan Francisco Manzano e seus mediadores: relações desiguais e silenciamentos, Trabalho de Conclusão de Curso. Instituto de Letras da Universidade Federal do Rio Grande do Sul. <001090598.pdf> (último acesso em 27/12/2020)

Macedo, Joaquim Manuel de (2005), As vítimas-algozes: quadros da escravidão, São Paulo, Zouk [1869]

Machado, Maria Helena Pereira Toledo (2019), "Maria Firmina dos Reis: escrita íntima na construção do si mesmo", in Estudos Avançados, Ago. 91-108. <https://www.scielo.br/ scielo.php?script=sci_arttext\&pid=S0103-40142019000200091> (último acesso em 14/08/2020)

Manzano, Juan Francisco (2015), Autobiografia do poeta-escravo Juan Francisco Manzano, Organização, tradução e notas de Alex Castro, Rio de Janeiro, Hedra [1835].

Massuela, Amanda. "Quem é e sobre quem escreve o autor brasileiro", in Revista Cult (2018). 05.02. 2018. < https://revistacult.uol.com.br/home/quem-e-e-sobre-o-que-escreve-o-autor-brasileiro/> (último acesso em 17/08/2020)

Mendes, Rogério (2019), Pedagogias da cimarronaje: a contribuição das cosmogonias e cosmovisões africanas e afrodescendentes para a crítica literária e literaturas (afro-) latino-americanas. Tese de Doutorado. Programa de Pós-Graduação da Universidade Federal de Pernambuco. <https://repositorio.ufpe.br/bitstream/123456789/35544/1/TESE\%20Rogerio\%20Mendes\%20Coelho.pdf> (último acesso em 14/08/2020)

Monteiro, Maria do Socorro de Assis (2019), "O subterrâneo intimismo de Úrsula: uma análise do romance de Maria Firmina dos Reis", in Letrônica, Jul. 361-381. <https://revistaseletronicas.pucrs.br/ojs/index.php/letronica/issue/view/377> (último acesso em 14/08/2020)

Ñíguez Bernal, Antonio (1987), "La nueva literatura hispanoamericana: estado actual", in Quinto Centenario: 37-96. <https://dialnet.unirioja.es/servlet/articulo?codigo=80401> (último acesso em 14/08/2020) 
Pedroso, Roberta Flores (2018), "A marca escravocrata na escrita de Maria Firmina”, Úrsula, edição comentada. Porto Alegre, Leitura XXI.

Rama, Ángel (1985), A cidade das letras, tradução de Emir Sader, São Paulo, Brasiliense.

Rama, Ángel (1982), La transculturación narrativa en América Latina, México, Siglo XXI Editores. Ramos, Liliam (2017), "Pode o tradutor falar? Uma análise da tradução da Autobiografía de Juan Francisco Manzano no Brasil sob a ótica dos Estudos Culturais", in Translatio. 251267. <https://seer.ufrgs.br/translatio/article/view/71641> (último acesso em 29/12/2020) Ramos, Liliam (2015), "(Re)cordar para (re)contar: representaciones de la protagonista negra en tres novelas históricas hispanoamericanas", Tese de Doutorado. Programa de Pós-Graduação em Letras da Universidade Federal do Rio Grande do Sul < https://www.lume. ufrgs.br/handle/10183/134132> (último acesso em 13/08/2020)

Reis, Maria Firmina (2018), Úrsula, Porto Alegre, Editora Figura de Linguagem [1959].

Silva, Régia Agostinho (2013), "A escravidão no Maranhão: Maria Firmina dos Reis e as representações sobre escravidão e mulheres do Maranhão na segunda metade do século XIX". Tese de Doutorado. Faculdade de Filosofia e Letras da Universidade de São Paulo. <https:// www.teses.usp.br/teses/disponiveis/8/8137/tde-14032014-094659/pt-br.php> (último acesso em 12/08/2020)

Silva, Régia Agostinho (2011), "A mente, essa ninguém pode escravizar: Maria Firmina dos Reis e a escrita feita por mulheres no Maranhão", in Leitura: Teoria e Prática, Jun. 11-19. <https://ltp.emnuvens.com.br/ltp/article/view/52> (último acesso em 12/08/2020)

Sommer, Doris (2004), Ficciones fundacionales: las novelas nacionales de América Latina, Tradução de José Leandro Urbina y Ángela Pérez. Bogotá, Ediciones Fondo de Cultura Económica. 